\title{
Legal Regulations System in The Implementation Process of Geothermal District Heating Investments
}

\author{
Tünde Jenei \\ University of Debrecen Faculty of Engineering \\ jeneit@eng.unideb.hu \\ Judit T. Kiss \\ University of Debrecen Faculty of Engineering \\ tkiss@eng.unideb.hu
}

\begin{abstract}
Geothermal investments change both the natural and the built environment. They affect water resources under the Earth's surface as well as the natural landscape itself. Regulations of authority permit procedures apply to various subunits of the environment and occur at certain stages of the investment. This paper examines how transparent and consistent regulations are as well as what difficulties the investors could have during the different authorisation processes, which could influence the implementation of the project. Process analysis was used to examine domestic and international regulatory practices. We examine the stages where the required authorisation procedures for the construction of geothermal investments occur in the implementation process and what role the individual permits play in the process of the investment. The research found that the authorization process is extremely long and very complicated.
\end{abstract}

Keywords: energy regulation system, geothermal energy, direct heating utilisation, geothermal investment

\section{INTRODUCTION}

In general, Hungary supports the generation of heat required for district heating, especially if the heat source is produced using gaseous fuels. At present, not many renewable energy sources are suitable for use in district heating. We can only estimate how the future will influence decision makers if district heating continues to be significant and renewable energy sources in the district heating sector will have to be used to a greater extent than at present, as political and financial support will be essential in this case [1].

When a geothermal investment is implemented, geological, technical, economic, legal, and financial and a few additional conditions must be met. In order to set up and operate geothermal heat investments, the investor must start several authorization procedures have to be initiated. In this paper, we review licensing procedures related to the establishment and operation of geothermal heat investments based on the laws and regulations in force. The investigated official procedures refer to investments directly exploiting geothermal energy extracted from the earth's crust, less than 2,500 meters from the natural surface. There are regulations other than those described above for utilizing energy recovered from layers deeper than 2,500 meters. According to the law, geothermal energy below $2,500 \mathrm{~m}$ can be exploited through a concession tender. 


\section{EXAMINATION OF REGULATORY BACKGROUND APPLYING TO GEOTHERMAL INVESTMENTS}

As a first step, we grouped the authorization procedures according to which environmental units are affected during the investment, its implementation and operation. These procedures include environmental permits; water permit, construction permit and energy permit procedures. The conduct of these procedures is regulated by the provisions of five laws, which are as follows:

- $\quad$ Act XLVIII of 1993 on mining

- Act LIII of 1995 on the general rules on environmental protection,

- Act LVII of 1995 on water management,

- Act LXXVIII of 1997 on the shaping and protection of built environment,

- Act XVIII of 2005 on district heating,

In addition to the provisions of the five acts, a number of other statutory implementing regulations have to be followed for a geothermal project. It is a feature of the statutory regulation that none of them regulates the implementation and operation of renewable energy investments solely and exclusively. In order to establish geothermal investments, each law needs to be examined in detail in order to apply the relevant regulations (paragraphs) and to obtain all permits.

As a second step in the study, the geothermal investment was divided into four main phases, which are the following:

- research phase,

- planning phase,

- implementation phase,

- Operational phase.

These phases cover the entire investment and implementation process, from which investors decide to invest in a geothermal project in the given region. The various stages of the investment are characterized by different legal environments, which is why the process and conditions for obtaining the permits specified by the authorities at each stage are described in separate sections. In order to implement a geothermal district heating system, the investors have to start several different procedures, which they can do with the permits previously acquired at some stage of the project's readiness. It can be stated that there is no legal contradiction in the regulation and there is no area or activity that would not be covered by the five mentioned laws and related regulations.

The implementation of licensing procedures would be simplified by a law that regulates the acquisition of the necessary permits for the implementation, the number of licensing authorities and their authorization rights, taking into account the specificities of renewable energy investments, including geothermal energy investments.

\section{GENERAL INTRODUCTION OF AUTHORITY PROCEDURES IN THE FOUR PHASES OF GEOTHERMAL INVESTMENTS}

Figure 1 illustrates the process of a geothermal investment according to the previously mentioned phases, and the time of each application for authorization in this flowchart.

In the figure, the process of a geothermal investment can be traced along the full black arrows. In each of the four phases, the events that characterize and take place in the given section give the process a frame. 
Figure 1 shows the prerequisites for a given event and the results of the sub-given event following the event. On the other hand, it is also evident that where and under what conditions the individual licensing procedures fit into the implementation process of the investment. Separately, we identified where information processes are taking place and where the legal procedures happen. The flow of information is marked with arrows drawn in a continuous line, and the legal procedures is represented in each phase with dashed arrows.

It can be seen in figure 1 that on the basis of individual requests for administrative action, the applicant is in possession of an authorization, depending on where the applicant initiated the action. These permissions were introduced in the „Process prerequisites, information” column. For example, in the planning phase, one of the sub-activities is the planning of underground parts of the production and re-injection wells, and the planning of the surface structures and technological equipment of the district heating plant. A prerequisite for starting a planning activity is obtaining an environmental permit and a preliminary water rights permit. The result of the planning activity is that the facility plans, which are the prerequisites for obtaining a water rights permit, will be completed and then the application for the building permit will be initiated.

It can also be seen in figure 1 that the application for and obtaining a permit for environmental protection, water rights, construction or district heating is required for the implementation of a geothermal investment at every stage of the investment. The individual permits are prerequisites of each other, i.e. application for a district heating installation permit can only be submitted if the investor holds environmental protection, water rights and construction permits. Hereinafter, sub-events taking place in the individual phases shown in figure 1 are introduced in a few sentences.

\subsection{Research phase}

Prior to starting permit procedures, it is necessary to clarify the ownership of the area in which the project will be implemented. If the investor is not the owner of the site, then the consent of the owner to submit the application must be requested before each licensing procedure is initiated.

During the research phase, the builder must obtain four preliminary permits to start the research in the designated area.

These are the following (see figure 1):

- Preliminary surface exploration permit.

- Research permit.

- Preliminary water rights permit.

- Preliminary construction permit.

Exploration drills are based on permits, which include the drilling of exploration wells for both production and injection. After processing the physical-chemical parameters of the thermal water that can be obtained from the wells, the examination of the yield of the wells and finally the testing of the production-injection system is carried out.

\subsection{Planning phase}

At this stage, it is necessary to obtain four permits to carry out the planning of the underground and surface facilities. The four permits are as follows (see figure 1).

- Environmental protection permits (see environmental impact assessment). 
- Water rights permit.

- Construction permit.

- District heating construction and operation permit.

\subsection{Implementation phase}

The implementation phase basically involves the construction of the thermal power plant and the thermal water pipeline and heat zone. The final activities of the phase are the trial operation and putting the completed constructions into operation. In this phase, three different permits are required to start operation after the facility has been built. These are as follows (see figure 1).

- Water rights operation permit.

- Application for occupancy permit.

- District heating production facility operational permit.

\subsection{Operational phase}

In the case of geothermal systems, there are specific measures and tests for operation, as described in 101/2007. (XII/23) KvVM (Ministry of Rural Development). These are mandatory tasks and tests that must be specified in the operational rules of the facility

On the basis of the tests carried out, the results obtained and their evaluation must be sent to the competent mining inspectorate within one month of the inspection.

In the operation of geothermal wells, the operator is required to pay two different taxes (see figure 1):

- water resource use tax,

- mining tax.

The payment of the water resource contribution is provided for in Act LVII of 1995 on water management. In Hungary, contribution must be paid according to Act LVII of 1995 on water management after the water supply was recovered and used for economic purposes. Under $\S$ $15 / \mathrm{C}$ of this act, a user does not have to pay a water supply contribution if the cooled water is reinjected into the aquifer under the water rights permit. The obligation of re-injection has been applied to all energy investments since 2004; i.e. when the production wells are established, the re-injection well must also be constructed. The re-injection well is not different from a technological and financing aspect from the thermal water producing well. This means that if we use the extracted hot water for energetic purposes, both the extraction and the re-injection well have to be drilled (or wells depending on how big the yield of the production well is). At present, when thermal water is used in agriculture it is not mandatory to return the used hot water to the aquifer.

The use of geothermal energy for heating in greenhouses is advantageous both from an environmental and economic aspect; however, the fact that under current regulation, as of December 22, 2020, it will be mandatory to pressurize the greenhouses, may worsen the use of geothermal energy [2]. The thermal water extracted and used for balneology purposes does not need to be reinjected, in which case the water resource use tax is payable. The mining tax is determined in accordance with Act XLVIII of 1993 on mining Government Decree 54/2008; 8/A $\S$ Section 1-2 of the latter deals with the determining of the unit value of mineral raw materials and geothermal energy as well as the method of calculating the value. According to Section 20 of the mining act, the state is the owner of the natural geothermal energy. 
The energy that the geothermal energy company uses for energy purposes is transferred to the enterprise through recovery. After the recovered geothermal energy, the state is entitled to a share, mining fee. A natural or legal person or a company without legal entity that recovers geothermal energy for energy purposes must pay mining royalties. The mining tax for the extracted geothermal energy must be paid to the mining authority. The mining fee must be calculated and declared on the basis of a self-declaration of specified content. The selfdeclaration must be sent to the Hungarian Mining and Geological Bureau at the same time as the payment. No mining tax must be paid if more than $50 \%$ of the extracted geothermal heat is used for heating and domestic hot water, and there is no mining tax for geothermal energy extracted from an energy source below $30^{\circ} \mathrm{C}$.

\section{ANALISYS OF DOMESTIC AND INTERNATIONAL REGULATORY PRACTICE}

\subsection{Domestic regulatory practice}

Table 1 summarizes the types of licensing procedures that arise during the implementation of a geothermal investment. The authorities to which different authorization applications are to be submitted and where licenses are issued at the end of the process are assigned to this. The regulations define the length of administrative procedures, which are listed alongside the authorities. The table shows that different authorities require different time periods for each authorization.

There are also two organizations that do not have a deadline for compliance (see table 1), these two organizations are the Ministry of Rural Development as the authority of state-owned waters and the Hungarian National Asset Management Inc. as the owner of groundwaters. Thus, it is unpredictable how much time the assessment of applications might take for these organizations, and as a result the implementation of the investment becomes uncertain.

In addition to the administration time, the amount of procedural fee to be paid to the authorities is regulated. These fees must be paid to each authority separately for each application. For each authority, the amount of and the basis for determining the procedural fees are different. There are authorities where you have to pay lump-sum fees (e.g. Ministry of Rural Development), but there are offices where fees are charged based on some performance parameters of the facility (e.g. in case of the Hungarian Energy and Public Utility Regulatory Authority, the procedural fee must be paid based on the performance of the facility). As a result of these procedures, the authorities issue permits after which either the investor initiates a new procedure or the investment is carried out within the legal framework justified by the permit.

Table 1: Service length of administration of individual permit processes

\begin{tabular}{|l|l|l|}
\hline Description of procedures & $\begin{array}{l}\text { Name of the competent } \\
\text { authority conducting } \\
\text { the procedure }\end{array}$ & $\begin{array}{l}\text { Authority's statutory } \\
\text { administration time }\end{array}$ \\
\hline \multirow{2}{*}{$\begin{array}{l}\text { 1. Environmental licensing } \\
\text { procedures (Government Decree }\end{array}$} & $\begin{array}{l}\text { Environmental, Nature } \\
\text { Conservation and Water } \\
\text { No. } 347 / 2006 . \text { Government }\end{array}$ & $\begin{array}{l}\text { Preliminary environmental } \\
\text { study: 33 days }\end{array}$ \\
\cline { 2 - 3 } Decree No. 314/2005.) & $\begin{array}{l}\text { In case of public hearing: 45 days } \\
\text { Inspectorate) }\end{array}$ & $\begin{array}{l}\text { Time for application procedure } \\
\text { for obtaining environmental } \\
\text { permit, environmental impact } \\
\text { assessment: at most } \mathbf{9 0} \text { days }\end{array}$ \\
\hline
\end{tabular}




\begin{tabular}{|c|c|c|}
\hline \multirow{3}{*}{$\begin{array}{l}\text { 2. Water licensing } \\
\text { procedures (Government } \\
\text { Decree No. 147/2010.) }\end{array}$} & $\begin{array}{l}\text { Environmental, Nature } \\
\text { Conservation and Water } \\
\text { Inspectorate (in brief: } \\
\text { Inspectorate), such authority } \\
\text { gives permission. }\end{array}$ & $\begin{array}{l}\text { Administrative deadline per } \\
\text { license type: } \mathbf{6 0} \text { days. } \\
\text { The deadline to remedy the } \\
\text { deficiencies in the notice of } \\
\text { receipt of the request } \mathbf{1 0} \text { days. }\end{array}$ \\
\hline & $\begin{array}{l}\text { Environmental, Nature } \\
\text { Conservation and Water } \\
\text { Inspectorate (in brief: } \\
\text { Inspectorate) as the state- } \\
\text { owned water operator } \\
\text { gives permission. }\end{array}$ & \multirow{2}{*}{$\begin{array}{l}\text { The Board of Directors and the } \\
\text { Trustee do not set a legal deadline, } \\
\text { because they are involved not as } \\
\text { an authority but as an owner or } \\
\text { as a manager of state property. }\end{array}$} \\
\hline & $\begin{array}{l}\text { Hungarian State Holding } \\
\text { Company, such as groundwater } \\
\text { owner gives permission. }\end{array}$ & \\
\hline \multirow{3}{*}{$\begin{array}{l}\text { 3. Building licensing } \\
\text { procedures (Government } \\
\text { Decree No. } 343 / 2006 .)\end{array}$} & \multirow{3}{*}{$\begin{array}{l}\text { Territorial Competent Authority } \\
\text { of the Hungarian Trade } \\
\text { Licensing Office Territorial } \\
\text { Measurement and Technical } \\
\text { Safety Authority is the Building } \\
\text { Authority for structures } \\
\text { connected to water facilities. }\end{array}$} & $\begin{array}{l}\text { Conceptual building permit } \\
\text { process: } 22 \text { workdays }\end{array}$ \\
\hline & & Building permit process: $\mathbf{4 5}$ workdays \\
\hline & & Usage licensing process: 22 workdays \\
\hline $\begin{array}{l}\text { 4. District heat production and } \\
\text { service licensing procedure } \\
\text { (Government Decree No. } \\
\text { 320/2010. Government } \\
\text { Decree No. } 157 / 2005 \text {.) }\end{array}$ & $\begin{array}{l}\text { Hungarian Energy and Public } \\
\text { Utility Regulatory Authority }\end{array}$ & $\begin{array}{l}\text { District heating plant establishment } \\
\text { and operating authorization } \\
\text { procedure: } 90 \text { days }\end{array}$ \\
\hline
\end{tabular}

Source: own research

Regulations define the validity period for each issued permit. These deadlines are usually between one and two years and are normally extendable once.

In order to eliminate the current complex and complex administration, it might be possible to place geothermal investments under the authority of one authority by changing the statutory regulations, and would not distinguish between the depths of the geothermal energy recovered.

Based on the above, we make the following statements regarding the legal regulation of geothermal investments:

- There is no contradiction in the regulation of the investment process and there is no area or activity that would not be covered by some regulation or law.

- Each permit application is based on each other, appearing as a prerequisite for each other in the authority application procedure. Figure 1 shows the order of the permit applications indicated in each section as regulated by law. In the figure above, the permit indicated as first must be submitted first or the subsequent applications cannot be initiated without the previously obtained permits. 


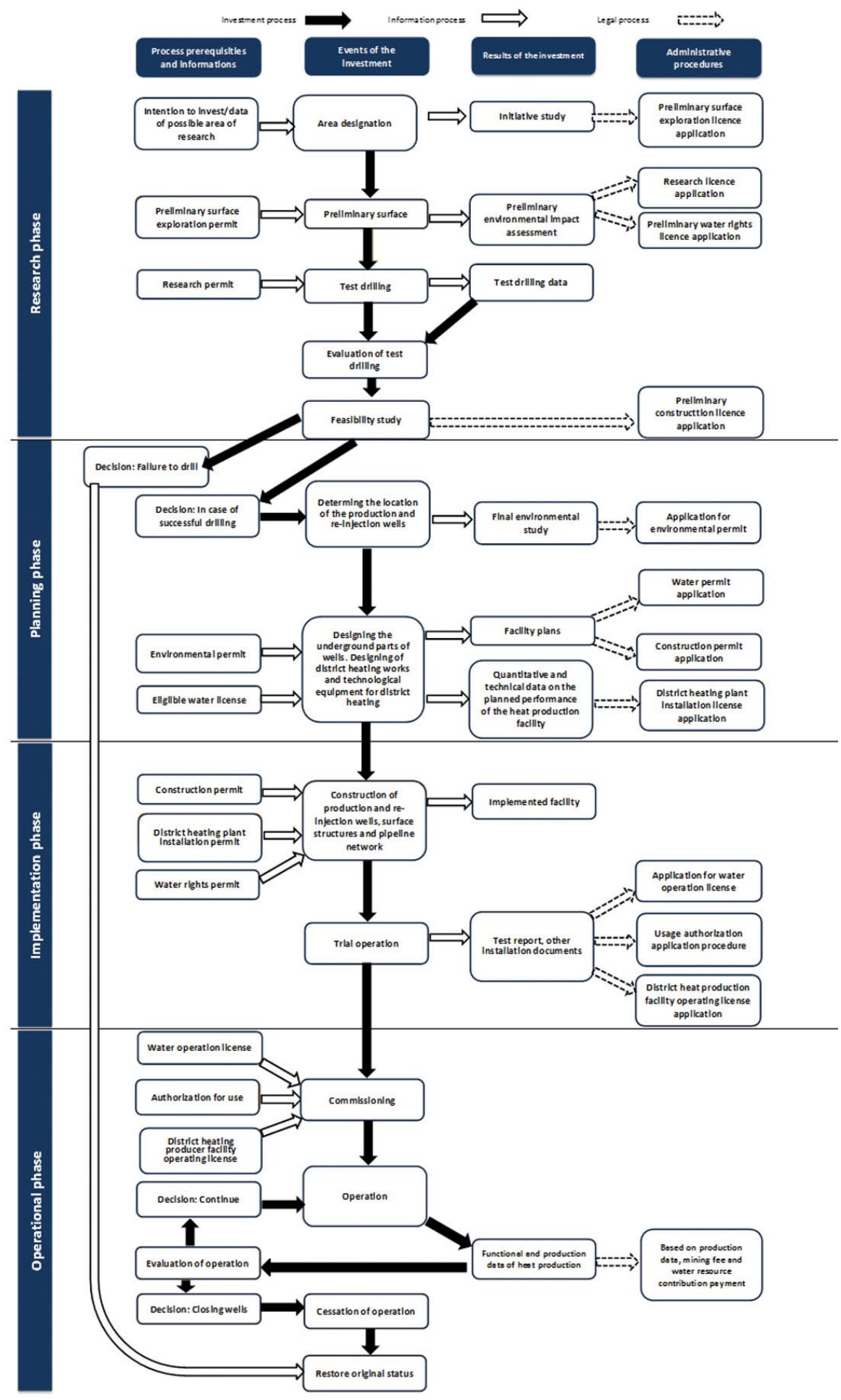

Figure 1: Authority procedures in each phase of geothermal investments Source: own research 
- Simpler administrative procedures would be required instead of complex multi-stage permit procedures with high administrative costs. To do this, a law regulating the use of renewable energy should be established, which would regulate and put the conditions for the establishment and operation of renewable energy investments into a framework. This would allow investors, producers and users in this segment of the energy sector to operate in a predictable, transparent legal environment.

\subsection{International regulatory practice}

In many countries around the world, such as Costa Rica [8], Canada [9], Indonesia [16], and Peru [19], the use of geothermal energy is regulated by individual laws. As in Hungary, there are eight different laws to be followed in Kenya, such as laws governing forests, water and game management [3] [13]. Geothermal energy developments are regulated in different ways in some member states of Australia. In Queensland, a separate law has been applied since 2010 [14], while in Western Australia one law regulates oil mining and geothermal energy use [15]. In the United States, geothermal energy was first regulated by law in 1967, in the state of California [4]. Later in 1970, the use of thermal water [5], [6] was unified in federal law in the whole country. In Europe, Italy [17] and Turkey [7], [10], [18] possess significant geothermal energy and regulations of individual legislation must be followed for geothermal energy use. The legal regulation of geothermal investments was examined and compared by experts from four countries in the framework of the "TRANSENERGY" project in Slovenia, Austria, Slovakia and Hungary.

The results [11] were summarized as follows:

- Geothermal energy sources are state-owned everywhere except Austria where the owner of the underground energy source is the land owner.

- The competence of thermal water recovery is the responsibility of several ministries everywhere, but the areas of responsibility in Hungary are the most fragmented. In the countries examined, water and / or environmental ministries supervise the activity.

- Geothermal concession is only in Hungary for the extraction of thermal water below $2,500 \mathrm{~m}$. In this case, the permit procedure is also different from the authorization procedure for aquifers above $2,500 \mathrm{~m}$ depth.

- The obligation to carry out an environmental impact study based on water recovery rates and performance in the four countries is roughly the same.

- Reinjection obligation in case of water recovery for energy purposes is in effect in Slovenia, Austria and Hungary for the total recovered quantity, there is no general obligation in Slovakia, it is decide on an individual basis and the decision is recorded in the water permit.

- Monitoring (which refers to the quantity and quality of thermal water production and the current state of the thermal well) and the provision of data within the state framework is regulated in all countries except Austria, where there is no unified monitoring system.

- There is no unified specific law regulating renewable energy investments in the four countries examined.

A practical example [12] confirms that the Renewable Energy Act, adopted in 2008 in Germany, has played a major role in boosting the German geothermal industry, supporting geothermal development through an extensive incentive system for the promotion of geothermal district heating from renewable energy sources. Today, energy production from thermal water production takes place in 180 geothermal facilities in Germany, with the vast majority of 
wells producing and re-injection wells with a capacity of about $260 \mathrm{MWt}$. Electric power is produced by six power plants: Unterhaching, Landau, Grünwald, Dürrnhaar, Kirchstockach and Sauerlach, with a combined electrical capacity of $27.1 \mathrm{MWe}$ and $122 \mathrm{MWt}$ of district heating systems [12]. In addition, a number of new geothermal power plants and district heating systems are under construction.

\section{CONCLUSIONS}

In the study, we examined the official licensing procedures related to the establishment and operation of geothermal heat investments based on the laws and regulations in force. We wanted to identify how consistent and transparent the regulatory rules are from an investor's point of view and what difficulties an investor may have in each permit process.

For the implementation of a geothermal district heating system, the investor must now comply with the provisions of five different laws, as well as a number of regulations related to the law. At each stage of the project, investors must initiate several different procedures that they can do with the previously acquired permits. It can be stated that the legal process is complex, but nevertheless, the regulation is consistent and contains no contradiction.

It would be necessary to simplify the administrative procedure because each stage of an investment process is too regulated; permit processes are lengthy and costly. A law on renewable energy should be established that takes the specificities of renewable energy investments and energy production into account. This would provide a more transparent legal framework for investors, producers and users alike. Based on international practices, it can also be stated that specific renewable energy laws have had a very good impact on the growth of geothermal energy investments. In Germany, the introduction of the law in 2008 greatly increased the number of geothermal investments. In order to increase domestic investment, creating conditions similar to those in Germany would be very helpful.

\section{REFERENCES}

\section{Articles}

[1] B. Horváth, M. Böröcz, S. Zsarnóczay, Cs. Fogarassy (2016) Long-term Green Innovation Opportunities within the Hungarian District-Heating Sector Towards 2030. Ybl Journal of Built Environment 4:1. pp:12 - 24.

[2] J. Nagygál, L. Tóth, B. Horváth, Cs. Fogarassy (2018): Thermal Water Utilization in the Hungarian Greenhouse Practice. Thermal Science 2018. Vol. 22. No: 2. pp: 1015 - 1024.

[3] F. M. Mwawughanga (2005): Regulatory Framework for Geothermal in Kenya. Proceedings World Geothermal Congress Antalaya, Turkey 24-29 April 2005.

[4] J. W. Lund-R. G. Bloomeuist (2012): Development of Geothermal Policy in the USA: What Works and Doesn't Work? GEO-HEAT CENTER Quarterly Bulletin 2012 February Vol. 30. No. 1. pp: 1-8.

[5] J. Milliken (2011): Geothermal Technologies Program; Peer Review Program, Office of Energy Efficiency and Renewable Energy USA DOE.

[6] R. G. BLоомquist (2003): United States Geothermal Policy - Provision of Access and Encouraging Project Development. Proceedings International Course on Resources - International Geothermal Conference Reykjavik Iceland 2003.

[7] N. KARTAL, (2013): Geothermal energy law in Turkey, http://www. martindale.com/energy-law/article_Senguler SengulerLawOffice_1706800.htm accessed June 17, 2015.

[8] A. Mainieri, (2006), Laws and regulations on geothermal energy utilization in Costa Rica, Workshop for Decision Makers on Geothermal Projects in Central America organized by UNU-GTP and LaGeo, 26 November, 2006, http://www.os.is/gogn/unu-gtpsc/UNU-GTP-SC-02-18.pdf, accessed April 21, 2016.

[9] Pembina (2011): Building a regulatory framework for geothermal energy development in the NWT. http://www.pembina.org/pub/2215, accessed August 5, 2011. 
[10] O. SEREF, (2010): Geothermal regulations and incentives under Turkish law, September 2010, http://www.gsimeridian.com/ files/17.pdf, accessed June 17, 2015.

[11] Nádor A. ET AL. (2012): A geotermikus energiahasznosítás jogszabályi - engedélyeztetési környezete a Transenergy országokban, „Termálvizek az Alpok és a Kárpátok ölelésében”című konferencián elhangzott előadás- Budapest, 2012. szeptember 13.

[12] Sanner, B. ET AL. (2015): Geothermal Energy Use in Germany, Proceedings World Geothermal Congress, Melbourne, Australia

\section{Acts and Decrees}

[13] Laws of Kenya Geothermal Resources Act. National Council for Law Reporting with the Authority General Revised Edition 2012.

[14] Geothermal Energy Act 2010. Queensland Australia

[15] Petroleum and Geothermal Energy Act 1967. Western Australia Version 08-CO-01 as at 15. November 2017.

[16] Indonesia, Law on geothermal, 2014 No. 21.

[17] Italy Riassetto della normativa in materia di ricerca e coltivazione delle risorse geotermiche, a norma dell'articolo 27 , comma 28, della legge 23 luglio 2009, n. 99. (10G0037) (Reorganization of the legislation on exploration and production of geothermal resources, in accordance with Article 27, paragraph 28 of Law July 23, 2009, n. 99. (10G0037)).

[18] Turkey, Law on geothermal resources and mineral waters, Law No.5686, 2007, http://gis.nacse.org/rewab/docs/Law_5685_Geothermal_and_Natural_Mineral_Waters_2007_En.pdf, accessed June 17, 2015.

[19] Peru, The organic law on geothermal resources No.26848 /1997, http://libopac.jica.go.jp/images/report/12048518_02.pdf, accessed April 21, 2016.

[20] Act XLVIII of 1995 on Mining

[21] Act LVII of 1995 on Water Management

[22] Act LIII of 1995 on General Rules of the Environmental Protection

[23] Act LXXVIII of 1997 on the Shaping and Protection of the Built Environment

[24] Act LVII of 2005 on District-heating

[25] Government Decree No. 54/2008 on the determination of the specific value of mineral resources and geothermal energy and the method of calculating value

[26] Government Decree No. 101/2007 on the professional requirements for groundwater intervention and water well drilling

[27] Government Decree No. 147/2010 on general rules for activities and installations for the recovery, protection and remediation of waters

[28] Government Decree No. 157/2005 on implementation of XVIII of 2005 on District Heating Services

[29] Government Decree No. 314/2005 on Environmental Impact Assessment and the integrated environmental authorization procedure

[30] Government Decree No. 320/2010 of the Hungarian Trade Licensing Office and the regional metrological and technical security authorities.

[31] Government Decree No. 343/2006 on the Designation and Operating Conditions of Construction and Building Supervision Authorities

[32] Government Decree No. 347/2006 on the designation of bodies responsible for environmental, nature conservation, water authority and administrative tasks 